ORIGINAL ARTICLE

\title{
Efficacy of exercise training program on performance in musicians playing guitar
}

\author{
Meltem IŞINTAŞ ARIK ${ }^{1}$, Filiz CAN²
}

Purpose: It was aimed to investigate the efficacy of exercise training program on performance in musicians playing guitar. Methods: This study was carried out with 27 classical guitar players aged between 16-35 years old. After the musicians were included in the study, they were divided into the exercise group $(n=10)$, the home exercise group $(n=10)$, and the control group $(n=7)$ and were evaluated three times, before exercise, at the 6 th week and at the end of the 3 rd month. Musicians in the exercise group performed the exercises for 6 weeks ( 3 days a week) with a physiotherapist, while the exercises were given to the other group as home exercises program. The changes in the measurements of pain, music performance, and post-performance fatigue findings of the musicians in all three groups were analyzed by the split-plot ANOVA (SPANOVA) test for repeated measures from multivariate statistical analyzes.

Results: Pain level in both exercise groups were significantly decreased at the end of 6 weeks and 3 months (F: 4.238, $p<0.005)$. Performance parameters were showed significant improvements in the Exercise Group (F: 3.72, $p<0.005$ ).

Conclusion: In conclusion, exercises, whether performed by a physiotherapist or given as a home exercise program, are of great importance in increasing the music performance of musicians playing guitar.

Keywords: Pain, Exercise, Fatigue.

\section{Gitar çalan müzisyenlerde egzersiz eğitim programının performansa etkisi}

Amaç: Egzersiz eğitim programının gitar çalan müzisyenlerde performansa etkisinin araştırıması amaçlandı.

Yöntem: Bu çalışma 16-35 yaş arası 27 klasik gitarist ile gerçekleştirildi. Müzisyenler çalışmaya dahil edildikten sonra egzersiz grubuna $(n=10)$, ev egzersiz grubuna $(n=10)$ ve kontrol grubuna $(n=7)$ ayrıldı ve egzersiz öncesi 6 . hafta ve 3 . ayın sonunda olmak üzere 3 kez değerlendirildi. Egzersiz grubundaki müzisyenler 6 hafta boyunca (haftada 3 gün) egzersizleri fizyoterapist ile yaptı, diğer gruba ise egzersizler ev programı olarak verildi. Her üç gruptaki müzisyenlerin ağnı, müzik performansı ve performans sonrası yorgunluk ölçümlerindeki değişiklikler, çok değişkenli istatistiksel analizlerden tekrarlanan ölçümler için split-plot ANOVA (SPANOVA) testi ile analiz edildi.

Bulgular: Her iki egzersiz grubunda ağıı düzeyi 6 hafta sonunda ve 3 ay sonunda anlamlı olarak azaldı $(F: 4,238, p<0,005)$. Performans parametreleri egzersiz grubunda anlamlı gelişmeler gösterdi (F: $3,72, \mathrm{p}<0,005)$.

Sonuç: Sonuç olarak, ister fizyoterapist tarafından yapılan isterse ev programı olarak verilen egzersizler gitar çalan müzisyenlerde müzik performansının artırılmasında büyük önem taşımaktadır.

Anahtar kelimeler: Ağn, Egzersiz, Yorgunluk.

1: Kütahya Health Sciences University, Faculty of Health Sciences, Department of Physiotherapy and Rehabilitation, Kütahya, Turkey 2: Hacettepe University, Faculty of Physical Therapy and Rehabilitation, Ankara, Turkey.

Corresponding Author: Meltem Işıntaş Ark: meltem.isintasarik@ksbu.edu.tr

ORCID IDs (order of authors): 0000-0001-8162-9641; 0000-0003-0641-9956

Received: September 28, 2020. Accepted: January 23, 2021. 
$\mathrm{P}$ laying-related musculoskeletal disorders (PRMDs) are caused by repetitive movements in musicians. Burning, tiredness, tingling or pain that occur while playing are usually the first symptoms. These problems usually arise from the prolongation of playing time, often from difficult repertoires, and sometimes from playing different instruments. ${ }^{1-3}$

Playing-related musculoskeletal system disorders (PRMDs) often result in functional deficits in the long term. Problems that may arise due to this should be prevented before they become difficult to treat. It may be quite important to provide educational programs which include preventive exercises and preventive measures and recommendations with the purpose of ensuring that musicians gain positive habits while carrying on their profession. It holds great importance in terms of the sustenance of the musicians' careers for physiotherapists to identify newly developing problems that are liable to become severe in the beginning and provide them with guidance and to inform them about the diseases and draw their attention so that they give due importance to their health. Most of the few numbers of articles are focused on focal dystonia. 4-8 However, while the occurrence rate of focal dystonia in musicians is $10 \%$, the rate of PRMDs is nearly around $60-70 \% .9,10$ In other words, PRMD, which is the biggest problem of musicians, has not been clinically or scientifically brought into question much. A systematic review showed that professional and amateur string players are subject to development of PRMD. In a conclusion its emphases that low response rates were the most observed source of bias, and there is still a lack of publications with high methodological quality in the literature. ${ }^{11}$

When studies on musicians in the literature were examined, it was observed that rather than showing the effectiveness of exercise, most of the studies were about the incidence and rates of injury. ${ }^{3,12-16}$ Therefore, it was concluded that there is no sufficient and detailed study on training for exercises aimed at the elimination and prevention of musculoskeletal system problems in musicians playing guitar.

In addition to this, most of the researchers in the literature have engaged in studies involving musicians including all groups instead of special musician groups most of whom play a particular instrument. ${ }^{17-20}$ It is also possible to objectively assess performance in musicians playing a particular instrument. This will lead to a clearer picture of the effectiveness of the applications. However, due to musical instruments having very different structures and requiring different training techniques, postures and the use of different muscles, a greater number of randomized controlled studies on this topic are needed.

For this reason, our aim was to investigate the efficacy of exercise training program on performance in musicians playing guitar.

\section{METHODS}

This study was carried out on 27 musicians undergoing high school, undergraduate and graduate education and playing the classical guitar at Hacettepe University, Ankara State Conservatory Music Department, Bilkent University, Music and Performing Arts Faculty Music Department and Istanbul Technical University, Turkish Music State Conservatory. Although consent was taken from all 47 musicians prior to the study, 20 musicians withdrew of their own accord, providing certain reasons during the study. For this reason, this study was completed with 27 musicians.

Undergraduate and graduate students who had been professionally playing the classical guitar at the conservatory for at least 3 years or whose main instrument was the classical guitar and whose ages varied between 16-35 were included in the study.

Those who played a guitar other than the classical guitar, those whose main instrument was not the guitar, those who were amateur guitar players, those who had played for less than 3 years, those who had given more than a 3 month break to guitar playing, those who had previously undergone surgery on their upper extremities, those who were currently undergoing physiotherapy and rehabilitation or had undergone physical therapy and rehabilitation 3 months before and were regularly using a painkiller or a NSAID those who had focal dystonia or another neurological problem and musicians with an acute injury such as tendonitis were excluded from the study.

The students in the 1 st group of the 
students who were divided into 3 groups were provided with training on exercises for 6 weeks by a physiotherapist. The 2 nd group was given the exercises as a home exercise program, and they were asked to practice these exercises for 6 weeks. The 3rd group was taken as a control group and was only assessed without being given exercises. Students in all groups were assessed for pain, performance and muscle fatigue at the beginning of the program, at the end of the 6 th week and at the end of the $3 \mathrm{rd}$ month.

This study, which was overseen by the Hacettepe University Medical, Surgical and Drug Research Ethics Committee with the number LUT091125 and was found appropriate in terms of medical ethics.

Our work was also supported by the Hacettepe University Scientific Research Unit (LUT09/125).

It was recorded how many hours a day and how many days a week the musicians included in our study played their instruments, in addition to for how many years they had been playing the instrument. ${ }^{21}$

Pain was assessed subjectively using the Visual Analogue Scale for Pain (VAS Pain). The musicians marked the degree of the pain they felt when playing an instrument on a line of 0 to $10 \mathrm{~cm} .^{22}$

Music performance was evaluated in three ways:

1. The length of time they can play without exhaustion: Musicians were asked to record the length of time they were able to play without exhaustion while practicing.

2. The length of time they can play at a certain metronomic speed: The length of time for which the musicians were able to play the guitar exercise given by their own music teachers at different metronomic speeds particular to each musician was recorded. At the beginning, determining a fixed metronomic speed and evaluating the length of time the musicians were able to play at this metronomic speed was considered. However, it was observed that because a fixed metronomic speed was not challenging enough for some musicians, they played for a long time. Or, on the contrary, this time was very short for musicians who had not yet attained this playing speed. The fact that the performance level and professional experience of all musicians were not equal rendered applying a fixed metronome speed to all musicians impossible. Because the real aim of this study was to measure the change in performance level within each musician and not the difference in performance between the musicians, a different metronomic speed was determined for each musician. For this reason, $70 \%$ of the maximum metronomic speed at which they could play was calculated for each student and the length of time for which they played at this speed was calculated for all three evaluations. Thus, the changes in performance in the musicians occurring before and after the practice and in the follow-up, period were evaluated and later the changes in performance in all 3 groups were compared with each other.

3. The duration of the muscle fatigue that occurs after playing the instrument: Musicians were asked to record the duration of the muscle fatigue that occurred after playing the instrument.

Exercise program

Before giving an exercise program to musicians, it was explained that exercise may cause muscle fatigue, but that it should not cause an increase in pain. It was asked of the musicians to perform the exercises at least 3 times a week, with 10 repetitions for 6 weeks. ${ }^{23,24}$

The exercises were both practically demonstrated and given as written material to the home exercise program group. Care was taken to ensure that the exercises were easy to learn, and the written instructions were easy to understand and safe. ${ }^{24,25}$ In addition, they were asked to keep an exercise journal and record how they did the exercises. However, in the assessment that was done at the end of the 6 th week, the musicians reported either that they had lost their exercise journals or that they had failed to keep them regularly. For this reason, no evaluation was done regarding the exercise journals.

The exercise program applied to the exercise and home exercise program groups included stretching exercises (stretching the forearm extensors, stretching the forearm flexors, stretching the forearm pronators, 
stretching the shoulder joint posterior capsule, stretching the shoulder joint anterior capsule, general stretching of the upper extremities, pectoral stretching, stretching the levator scapula, stretching the lumbar extensors, stretching the entire spine, stretching the hip flexors), posture exercises and strength building exercises (strengthening the wrist extensors, strengthening the elbow flexors, strengthening the elbow extensors, strengthening the shoulder abductors, strengthening the shoulder flexors, bridging, abdominal strengthening, oblique abdominal strengthening, strengthening the back extensors, gluteus maximus isometric, alternative arm and leg lifting). Water bottles were used for wrist flexors, elbow flexors, elbow extensors, shoulder abductors and flexors muscles strengthening exercises.

The exercises were started with 5 repetitions and the number of repetitions was increased to 10 one by one according to their tolerance levels so as not to create pain and fatigue. The exercise program was started with stretching exercises, continued with posture and strength building exercises and ended with stretching exercises. The exercises were performed in combination with respiration. ${ }^{24}$

\section{Statistical analysis}

The Statistical Package for the Social Sciences version 13 for Windows (SPSS, Inc., Chicago, IL, USA) was used for the analysis of the data obtained. The assumptions required for the analyses (normality, homogeneity of variances and sphericity) were met. The conformity of the variables to normal distribution was examined using the Kolmogorov-Smirnov/Shapiro-Wilk tests, Box's M test and Mauchly's sphericity test.

Descriptive analyses for demographic findings were given using frequency, percentile, mean and standard deviation. When examining the changes in the pre-exercise, post-exercise and 3rd month follow-up measurements of the pain and fatigue symptoms of individuals in the exercise, home exercise program and control groups, the Split Plot ANOVA (SPANOVA) test for repeated measurements was used from multivariate statistical analyses. In cases when the assumption of sphericity was not met, the Greenhouse-Geisser correction was used. The Tukey HSD test was performed for the source of the variance and the significance of the difference between means. The statistical significance level was accepted as 5\% $(p=0.05)$ and analyses were interpreted accordingly. ${ }^{26}$

\section{RESULTS}

The Exercise Group with a mean age of $21.4 \pm 3.627$ (18-31) years, the Home Exercise Group with a mean age of $21.5 \pm 4.034$ (15-26) years and the Control Group with a mean age of $27 \pm 4.320(22-35)$ years were included in the study. The mean height of the exercise group was $178.4 \pm 4.325(170-185) \mathrm{cm}$, the mean height of the home exercise group $178.7 \pm 7.874$ (164192) $\mathrm{cm}$ and the mean height of the control group $177.857 \pm 10.106 \quad(163-196) \quad \mathrm{cm}$. The average weight of the exercise group was found as $70.7 \pm 10.242(59-93) \mathrm{kg}$, the average weight of the home exercise group as $72.5 \pm 12.518$ (50-85) $\mathrm{kg}$ and the average weight of the control group as $71.428 \pm 12.581(57-95) \mathrm{kg}$.

When the performances of the musicians were examined, it was observed that they played instruments for an average of $4(2-7)$ hours a day and 6.37 (3-7) days a week. Our study included musicians who had played guitar for 8.14 (3-15) years on average.

The home exercise group and the exercise group that attained more decrease in terms of pain during activity compared to before the training, were both found to be effective (F:4.238, p:0.005). However, only the difference between the exercise group and the control group averages was found to be significant. No significant difference was found between the activity pain level of musicians in the exercise, home exercise and control groups and the averages of the total measurement values obtained from all three evaluation measurements (F:2.921, p:0.073). The postexercise activity pain levels of musicians in all 3 groups showed significant improvement compared to before the exercise (F:15.113, $p<0.001)$. This result was also valid for the control group even though no exercises were given to this group (Table 1).

It was observed that while the length of time for which the musicians in both the exercise group and the home exercise group could play without exhaustion increased after exercise, it decreased in the 3rd month follow-up and that that it increased slightly only in the 3rd month follow-up for the control group. A 
significant difference was found between the averages of the total measurement values obtained from all three measurements of the findings pertaining to the length of time the students in the exercise, home exercise and control groups could play without exhaustion (F:1.363, p:0.275). There was no significant difference between the exercise and control groups and between the home exercise and control groups. The length of time for which the musicians in the exercise group could play without exhaustion is longer. However, the increase in the home exercise continued until the final evaluation. It was found that there was a significant difference between the averages of the values from the first evaluation to the final evaluation of the length of time musicians involved in the study could play without exhaustion (F:4.439, p:0.017). In all three evaluations of the musicians, the length of time they could play without exhaustion had increased (Table 2).

The exercise group and the home exercise group were found to be more effective than the control group at increasing length of time for which they could play at a specific metronomic speed ( $\mathrm{F}: 3.554, \mathrm{p}: 0.033)$. There is a significant difference between the averages of the total measurement values obtained from all 3 evaluations of the length of time for which students in the exercise, home exercise and control groups could play at a specific metronomic speed (F:5.820, p:0.009). When the home exercise group is compared to the exercise and control groups, the averages of the length of time the musicians played is significantly longer. The difference between the exercise group and the control group averages was not found to be significant. It was found that there is a significant difference between the averages of the values from the first evaluation to the final evaluation of the length of time the musicians involved in the study could play at a specific metronomic speed ( $\mathrm{F}: 13.913, \mathrm{p}<0.001)$. When the measurement averages are taken into consideration, the 1st measurement, 2nd measurement and follow-up measurement values show an increase for the exercise and home exercise groups, however the time averages for the control group do not show a difference (Table 3).

It was found that the muscle fatigue duration of the musicians who were divided into three groups did not show a significant difference from before the exercise program to after and to the follow-up evaluation ( $\mathrm{F}: 1.406$, $\mathrm{p}: 0.256)$. Muscle fatigue duration did not differ between the groups during all 3 measurements. There is no significant difference between the averages of the total measurement values obtained from all 3 evaluation measurements of the muscle fatigue duration of students in the exercise, home exercise and control groups (F:3.142, p:0.061). When we look at post-hoc analysis, a difference was found only between the exercise and home exercise groups; the decrease in the muscle fatigue of the exercise group was seen to be greater. It was found that there was a significant difference between the averages of the duration of muscle fatigue of the musicians involved in the study from before the measurements to after the follow-up (F:3.727, $\mathrm{p}$ :0.045). According to this, the muscle fatigue duration of the musicians had decreased during the three measurements, but this decrease did not differ between the groups (Table 4).

\section{DISCUSSION}

As a result of this study which was conducted with the aim of determining the effectiveness of exercise training program on performance in musicians playing guitar, the early and late period effects of both the exercise training accompanied by a physiotherapist and the exercises given as a home exercise group were found to be statistically significant.

The musicians who participated in our study were reported to play for an average of 4 (2-7 hours) hours daily and 6.37 (3-7) days weekly. When their average years of performance were checked, it was found to be $8.14(3-15)$ years. These findings indicate that the daily practice times of guitarists in our study were longer than those of the musicians in the study by Can et al.. ${ }^{27}$ This may be since all the musicians in our study were students and therefore spent more time on daily performance due to exams or training. However, the daily performance time of all guitarists in our study being longer may be because they had not received training on prevention before and that $55 \%$ of them totally espoused the principle of "no pain, no gain", which in turn confirms the abundance of PRMD symptoms and increased 
Table 1. Pain level (Visual Analog Scale-VAS, cm) measurement results within and between groups.

\begin{tabular}{|c|c|c|c|c|c|c|}
\hline & Exercise & Home exercise & Control & \multirow{3}{*}{$\begin{array}{c}\text { Group } \\
\text { effect } \\
F(p)\end{array}$} & \multirow{3}{*}{$\begin{array}{l}\text { Time } \\
\text { effect } \\
F(p)\end{array}$} & \multirow{3}{*}{$\begin{array}{c}\text { Interaction } \\
\text { effect } \\
F(p)\end{array}$} \\
\hline & $\left(n_{1}=10\right)$ & $\left(n_{2}=10\right)$ & $\left(n_{3}=7\right)$ & & & \\
\hline & $X \pm S D$ & $X \pm S D$ & $X \pm S D$ & & & \\
\hline Pre-training & $4.13 \pm 2.85$ & $4.20 \pm 2.29$ & $4.77 \pm 3.11$ & \multirow{3}{*}{$\begin{array}{c}2.921 \\
(0.073)\end{array}$} & \multirow{3}{*}{$\begin{array}{c}15.113 \\
(<0.001)\end{array}$} & \multirow{3}{*}{$\begin{array}{c}4.238 \\
(0.005)^{* *}\end{array}$} \\
\hline Post-training & $0.88 \pm 1.41$ & $2.78 \pm 2.25$ & $4.02 \pm 3.37$ & & & \\
\hline Follow-up & $1.10 \pm 1.52$ & $1.83 \pm 1.87$ & $4.98 \pm 3.08$ & & & \\
\hline
\end{tabular}

${ }^{*} p<0.05 .{ }^{* *} p<0.01$. F: Split Plot ANOVA (SPANOVA) test.

Table 2. Length of time (sec) which they could play without exhaustion measurement results within and between groups.

\begin{tabular}{|c|c|c|c|c|c|c|}
\hline & Exercise & Home exercise & Control & Group & Time & Interaction \\
\hline & $\left(n_{1}=10\right)$ & $\left(n_{2}=10\right)$ & $\left(n_{3}=7\right)$ & effect & effect & effect \\
\hline & $\mathrm{X} \pm \mathrm{SD}$ & $\mathrm{X} \pm \mathrm{SD}$ & $\mathrm{X} \pm \mathrm{SD}$ & $F(p)$ & $F(p)$ & $F(p)$ \\
\hline Pre-training & $52.00 \pm 24.28$ & $50.50 \pm 28.91$ & $43.57 \pm 38.37$ & \multirow{3}{*}{$\begin{array}{c}1.363 \\
(0.275)\end{array}$} & \multirow{3}{*}{$\begin{array}{c}4.439 \\
(0.017)^{*}\end{array}$} & \multirow{3}{*}{$\begin{array}{c}1.548 \\
(0.203)\end{array}$} \\
\hline Post-training & $80.00 \pm 42.22$ & $71.50 \pm 28.28$ & $41.42 \pm 30.64$ & & & \\
\hline Follow-up & $63.50 \pm 27.79$ & $72.00 \pm 28.20$ & $51.42 \pm 35.67$ & & & \\
\hline
\end{tabular}

$* p<0.05$. F: Split Plot ANOVA (SPANOVA) test.

Table 3. Length of time (sec) for which they could play at a specific metronomic speed measurement result within and between groups (with mean difference between groups for length of time (sec) for which they could play at a specific metronomic speed measurement result).

\begin{tabular}{|c|c|c|c|c|c|c|}
\hline & $\begin{array}{c}\text { Exercise } \\
\left(n_{1}=10\right) \\
X \pm S D\end{array}$ & $\begin{array}{c}\text { Home exercise } \\
\left(\mathrm{n}_{2}=10\right) \\
\mathrm{X} \pm \mathrm{SD}\end{array}$ & $\begin{array}{c}\text { Control } \\
\left(\mathrm{n}_{3}=7\right) \\
\mathrm{X} \pm \mathrm{SD}\end{array}$ & $\begin{array}{l}\text { Group } \\
\text { effect } \\
F(p)\end{array}$ & $\begin{array}{l}\text { Time } \\
\text { effect } \\
F(p)\end{array}$ & $\begin{array}{c}\text { Interaction } \\
\text { effect } \\
F(p)\end{array}$ \\
\hline Pre-training & $33.80 \pm 9.44$ & $64.40 \pm 30.24$ & $44.34 \pm 21.21$ & & & \\
\hline Post-training & $49.40 \pm 8.72$ & $81.70 \pm 36.11$ & $44.66 \pm 19.21$ & $\begin{array}{c}5.820 \\
(0.009) * *\end{array}$ & $\begin{array}{c}13.913 \\
(<0.001)\end{array}$ & $\begin{array}{c}3.554 \\
(0.033)^{*}\end{array}$ \\
\hline Follow-up & $53.00 \pm 11.16$ & $85.90 \pm 40.12$ & $42.50 \pm 17.00$ & & & \\
\hline Groups & & \multicolumn{4}{|c|}{ Mean Difference (95\% Cl) } & $\mathrm{p}$ \\
\hline Exercise vs Home program & & \multicolumn{4}{|c|}{$-31.93(-58.43$ to -5.43$)$} & $0.016 *$ \\
\hline Home program vs Control & & \multicolumn{4}{|c|}{33.50 (2.89 to 64.09$)$} & $0.030 *$ \\
\hline Exercise vs Control & & \multicolumn{4}{|c|}{$1.56(-29.03$ to 32.16$)$} & 0.991 \\
\hline
\end{tabular}

${ }^{*} \mathrm{p}<0.05 .{ }^{*} \mathrm{p}<0.01$. F: Split Plot ANOVA (SPANOVA) test.

Table 4. Muscle fatigue duration (sec) measurement results within and between groups.

\begin{tabular}{|c|c|c|c|c|c|c|}
\hline & Exercise & Home exercise & Control & Group & Time & Interaction \\
\hline & $\left(n_{1}=10\right)$ & $\left(n_{2}=10\right)$ & $\left(n_{3}=7\right)$ & effect & effect & effect \\
\hline & $\mathrm{X} \pm \mathrm{SD}$ & $\mathrm{X} \pm \mathrm{SD}$ & $\mathrm{X} \pm \mathrm{SD}$ & $F(p)$ & $F(p)$ & $F(p)$ \\
\hline Pre-training & $88.00 \pm 67.13$ & $25.30 \pm 26.99$ & $69.92 \pm 80.68$ & \multirow{3}{*}{$\begin{array}{c}3.142 \\
(0.061)\end{array}$} & \multirow{3}{*}{$\begin{array}{c}3.727 \\
(0.045)^{*}\end{array}$} & \multirow{3}{*}{$\begin{array}{c}1.406 \\
(0.256)\end{array}$} \\
\hline Post-training & $45.00 \pm 33.08$ & $18.00 \pm 11.59$ & $56.42 \pm 63.94$ & & & \\
\hline Follow-up & $47.00 \pm 34.97$ & $27.00 \pm 27.10$ & $36.42 \pm 30.91$ & & & \\
\hline
\end{tabular}

${ }^{*} p<0.05$. F: Split Plot ANOVA (SPANOVA) test. 
risk of injury in musicians in our study.

In our study, when the pain levels felt by musicians while playing an instrument were examined, the pain levels of the exercise and home exercise groups were found to be significantly lower compared to the control group after the exercise program and in the follow-up evaluations. A difference was only found between the exercise and control groups, meaning that the average pain of musicians according to the VAS had decreased the most in the exercise group.

In a study that they conducted, Yurdalan et al. ${ }^{28}$ found the duration of practice related fatigue in musicians as $2.3 \pm 1.3$ hours. $62.5 \%$ of the musicians stated that they felt pain or numbness during the fatigue caused by playing an instrument and that they therefore felt the need to take a break from practicing.

In another study on the subject, it was found that in addition to reducing pain, a training in endurance exercises for the trunk muscles reduced the fatigue and perceived strain that occurred when playing in both groups. ${ }^{20}$ These results are consistent with the results of the study conducted by Ackermann et al. ${ }^{29}$, who found that endurance training is more effective than strength training at reducing the perceived strain felt when playing an instrument. After the exercise program, almost half of the participants reported that there was in increase in their endurance when playing an instrument. These findings support the hypothesis that endurance exercises have a positive effect on performance and allow musicians to play longer repertoires with less fatigue.

In our study, the fatigue duration times of students in the exercise group decreased significantly compared to the home exercise and control groups. These results have shown that regular exercise training done with a physiotherapist is quite effective at reducing the duration of fatigue. Because a reduction in the duration of fatigue is also an indication of increased performance in musicians, exercise training can be said to increase the performance of musicians.

Since there is no standardized evaluation scale for this subject on which there is consensus in the physiotherapy or music literatures, the length of time musicians could play without exhaustion or discomfort, the length of time they could play at a specific metronomic speed and the duration of the fatigue that occurred after playing were taken as parameters for evaluating performance in this study. In conclusion, a significant increase was found to take place in the playing times of all three groups. However, when the exercise and home exercise was compared with the control group, their average playing times were found to be significantly higher. Although the length of time students in the exercise group could play without exhaustion was longer after exercise, this time was found to be shorter than the home exercise group in the follow-up evaluation. This result, which was revealed during the follow-up period at the end of the 3rd month, and which favored the home exercise group, may be due to the home exercise group developing a more serious work discipline about continuing the exercises, whereas the group which was trained by a physiotherapist lost their exercise discipline after the program ended at the end of the 6 th week.

In our study, the performances of the guitarists were also evaluated by calculating the length of time for which they could play a guitar exercise assigned by their music teachers at a metronomic speed also determined separately by music teachers according to the capacity of each student. Once again, similarly, the average playing times of the exercise and home exercise groups were found to be significantly longer than that of the control group. However, home exercise group averages were found to be significantly higher than exercise group averages. This is like the results of the other parameters as favoring the home exercise group. This result, which shows the importance of maintaining the continuity of the exercises and of exercise discipline, is very important for musicians. In conclusion, exercise training and in particular, exercise training provided by a physiotherapist and performed regularly and uninterruptedly was found to be quite effective at increasing the performance levels of musicians who played the guitar, which is the first original study result in the literature in this respect, demonstrated by evaluation of objective data.

In a study conducted with the aim of assessing and comparing two therapeutic exercises aimed at increasing truncal and proximal upper extremity muscle endurance 
and neuromuscular control and determining the effects of these two changes on instrument playing performance, the participants reported a significant decrease in the pain, fatigue and perceived strain felt when playing an instrument. The researchers reported that when they compared the two exercise groups, they did not find a significant difference in trunk endurance and that therefore Pilates was as equally effective as the traditional truncal and proximal upper extremity endurance exercise program. ${ }^{20}$

Ross et al. used a rehabilitation program including an educational presentation, an 11week home exercise program and three supervised exercise sessions, versus no intervention. They suggested that the studied program is feasible and effective in decreasing the intensity and functional impact of musicians' symptoms. ${ }^{30}$

Cyganska et al. emphasis that exercise should be used regularly and significant results can be obtained after approximately two weeks of use. ${ }^{31}$ Similarly, a study using randomized controlled methods showed that physical exercise interventions potentially have a positive impact on instrument playing and exercises have potential positive effects on playing performance. ${ }^{32}$ Similar to the literature, it was found in our controlled study that the exercise training consisting of posture exercises and stretching and strength building exercises was quite effective at protecting musicians from musculoskeletal system injuries and improving their performance.

Studies emphasize the need to develop prevention programs for PRMDs among musicians, and physical exercises are recommended as the most effective intervention. ${ }^{31-34}$ Exercises should not be complicated so that the musicians can do the exercises properly and regularly after the training. In addition, exercises should be given to the muscles and areas exposed to overload and pain. ${ }^{35}$

\section{Limitations}

Although we started our study with 47 people, the study was completed with 27 musicians. The biggest limitation of this study was the small number of musicians playing classical guitar in our country (approximately 200 musicians), the fact that a very few universities and conservatories had classical guitar training, and the musicians who participated in the study stopped their exercise program. As the second measurement taken after the 6-week exercise program coincided with the final exam week of the students may also have affected some measurement results, especially the anxiety results. Musicians just make music exercises and performance of their work in Turkey. It has been difficult to motivate both students and instructors as the importance of physical exercises related to the whole body has not been established sufficiently yet. In conclusion, despite these limitations, this study does not have any significant limitations in terms of both clinical and method, equipment and parameters. Therefore, the results of this study can be considered for the literature.

\section{Conclusion}

As a result of the study, the effectiveness of physiotherapy was objectively demonstrated in order to prevent musculoskeletal system problems and to increase their performance in both students and musicians playing guitar professionally. For an effective treatment, detailed and correct evaluation is very important. Besides the classical evaluation, the evaluation must include the evaluations made while playing the instrument. Objective evaluations used in our study will guide physiotherapists in clinical practice. In today's world where disease prevention and disability prevention methods come into prominence and care rather than treatment of diseases and injuries; objective demonstration of the effectiveness of preventive physiotherapy in this profession will lead physiotherapists and researchers more towards community-based studies. For researchers, it will be an example and guide for future studies on those who play different instruments.

Acknowledgement: We would like to thank Prof. Kağan Korad for creating and evaluating the exercises performed on guitar.

Authors' Contributions: MIA: Study design, literature search, case referral, data analysis/interpreting, writing; FC: Study design, data interpreting, writing, critical review.

Conflict of Interest: None.

Funding: None. 
Ethical Approval: The protocol of the present study was approved by the Hacettepe University Medical, Surgical and Drug Research Ethics Committee, (issue: LUT091125 date: 9/12/2009).

\section{KAYNAKLAR}

1. Ostwald PF, Baron BC, Byl NM, et al. Performing arts medicine. West $J$ Med. 1994;160:48-52.

2. Potter PJ, Jones IC. Medical problems affecting musicians. Can Fam Physician. 1995;41:21212128.

3. Hansen PA, Reed K. Common musculoskeletal problems in the performing artist. Phys Med Rehabil Clin N Am. 2006;17:789-801.

4. Butler K. Neurology of Music. In: Neurology of Music. Rose FC, editor. London: Imperial College Press; 2010:424.

5. Butler K. Preventing Injuries In Guitarists: Focal Hand Dystonia. Acoustic Magazine. October 2011;18-22.

6. Butler K, Rosenkranz K. Focal Hand Dystonia Affecting Musicians. Part I: An Overview Of Epidemiology, PathoPhysiology And Medical Treatments. Br J Hand Ther. 2006;11:72-78.

7. Butler K, Rosenkranz K. Focal hand dystonia affecting musicians. Part II: An Overview of current rehabilitative treatment techniques. $\mathrm{Br}$ J Hand Ther. 2006;11:79-87.

8. Byl N, Archer ES, McKenzie A. Focal hand dystonia: effectiveness of a home program of fitness and learning-based sensorimotor and memory training. J Hand Ther. 2009;22:183-197.

9. Hoppmann RA, Reid RR. Musculoskeletal problems of performing artists. Curr Opin Rheumatol. 1995;7:147-150.

10. Foxman I, Burgel BJ. Musician health and safety: Preventing playing-related musculoskeletal disorders. AAOHN J. 2006;54:309-316.

11. Girgis B, Duarte JA. Efficacy of physical therapy interventions for chronic lateral elbow tendinopathy: a systematic review. Phys Ther Rev. 2020;25:42-59.

12. Bejjani FJ, Kaye GM, Benham M. Musculoskeletal and neuromuscular conditions of instrumental musicians. Arch Phys Med Rehabil. 1996;77:406-413.

13. Bragge P, Bialocerkowski A, McMeeken J. A systematic review of prevalence and risk factors associated with playing-related musculoskeletal disorders in pianists. Occup Med (Lond). 2006;56:28-38.

14. Lockwood AH. Medical problems in secondary school-aged musicians. Med Probl Perform Art. 1988;3:129-32.

15. Allsop L, Ackland T. The prevalence of playingrelated musculoskeletal disorders in relation to piano players' playing techniques and practising strategies. Music Perform Res. 2010;3:61-78.

16. Steinmetz A, Scheffer I, Esmer E, et al. Frequency, severity and predictors of playingrelated musculoskeletal pain in professional orchestral musicians in Germany. Clin Rheumatol. 2015;34:965-973.

17. Genç A, Altuntaşoğlu B, Özcan A. Müzisyen ve müzisyen olmayan olgularda el fonksiyonlarının karşılaştırılması. Fizyoter Rehabil. 2002;13:124128.

18. Shafer-Crane GA. Repetitive stress and strain injuries: preventive exercises for the musician. Phys Med Rehabil Clin N Am. 2006;174:827-842.

19. de Greef M, van Wijck R, Reynders K, et al. Impact of the Groningen Exercise Therapy for Symphony Orchestra Musicians Program on perceived physical competence and playingrelated musculoskeletal disorders of professional musicians. Med Probl Perform Art. 2003;18:156160.

20. Kava KS, Larson CA, Stiller CH, et al. Trunk endurance exercise and the effect on instrumental performance: a preliminary study comparing Pilates exercise and a trunk and proximal upper extremity endurance exercise program. Music Perform Res. 2010;3:1-30.

21. Bruno S, Lorusso A, L'Abbate N. Playing-related disabling musculoskeletal disorders in young and adult classical piano students. Int Arch Occup Environ Health. 2008;81:855-860.

22. Ferreira-Valente MA, Pais-Ribeiro JL, Jensen MP. Validity of four pain intensity rating scales. Pain. 2011;152:2399-3404.

23. Frederickson K. Fit to play: musicians' health tips. Music Educ J. 2002;88:38-44.

24. Otman S. Egzersizin siniflandirılması ve egzersiz programı planlama. In: Otman S, editor. Egzersiz Tedavisinde Temel Prensipler ve Yöntemler. 1st ed. Ankara: Meteksan; 2006:1016.

25. Bandy WD, Sanders B. Therapeutic exercise: techniques for intervention. Baltimore: Lippincott Williams \& Wilkins; 2001.

26. Hayran M, Hayran M. Sağlık Araştırmaları İçin Temel İstatistik. Ankara: Omega Araştırma; 2011.

27. Can F, Işıntaş Arık M, Erdem EU, et al. The influence of pain level and performance duration on upper extremity functions in guitar players. In: 1 International Congress for Musician' Health in the context of physical therapy, speech therapy and occupational therapy. Osnabrück, Germany; 2012:33.

28. Yurdalan U, Doğuluer M, Nilgün G. Öğrenci ve 
profesyonel düzeyde müzik icra edenlerde postür değerlendirmeleri. Fizyoter Rehabil. 1994;7:6372 .

29. Ackermann B, Adams R, Marshall E. Strength or endurance training for undergraduate music majors at a university? Med Probl Perform Art. 2002; $17: 33-41$.

30. Roos M, Roy J-S. Effect of a rehabilitation program on performance-related musculoskeletal disorders in student and professional orchestral musicians: a randomized controlled trial. Clin Rehabil. 2018;32:16561665.

31. Cygańska A, Truszczyńska-Baszak A, Tomaszewski P. Impact of exercises and chair massage on musculoskeletal pain of young musicians. Int J Environ Res Public Health. 2020;17:5128.

32. Nygaard Andersen L, Mann S, Juul-Kristensen $\mathrm{B}$, et al. Comparing the impact of specific strength training vs general fitness training on professional symphony orchestra musicians: a feasibility study. Med Probl Perform Art. 2017;32:94-100.

33. Chan C, Driscoll T, Ackermann BJ. Effect of a musicians' exercise intervention on performance-related musculoskeletal disorders. Med Probl Perform Art. 2014;29:181-188.

34. Spahn C, Voltmer E, Mornell A, et al. Health status and preventive health behavior of music students during university education: Merging prior results with new insights from a German multicenter study. Music Sci [Internet]. 2017;21:213-229.

35. Arnason K, Briem K, Arnason A. Effects of an education and prevention course for university music students on their body awareness and attitude toward health and prevention. Med Probl Perform Art. 2018;33:131-136. 